\title{
Physical Environment Home and Incidence of TB Disease in Tanjungpinang District
}

\author{
Rina Madhona ${ }^{1}$, Zainul Ikhwan², Fidyah Aminin ${ }^{3}$ \\ ${ }^{1}$ University of Sumatera Utara, Indonesia \\ rinamadhona@gmail.com \\ ${ }^{2}$ Envirotmental Health Study Program, Health of Tanjungpinang, Indonesia \\ zainul. ikhwanegmail.com \\ ${ }^{3}$ Midwide Study Program, Health of Tanjungpinang, Indonesia \\ fidyahaminin@yahoo.com
}

\begin{abstract}
In Tanjungpinang city, the incidence of pulmonary TB is still quite high. In 2011 as many as 2,536 suspected pulmonary TB smear positive cases examined and that as many as 216 patients. The year 2012 has been examined as many as 2,065 patients with chronic cough sputum specimens. The total positive for smear-positive bacteria as many as 184 specimens (District Health Office of Tanjungpinang, 2012). The purpose of this research is to know the relationship physical environmental risk factors (residential density, lighting, humidity and floor condition) with the incidence of TB Disease. This type of research is analytic observational. The research was conducted within the period Mei - September 2013, and case-control design. Sampled study subjects were 70 people, (35 smears positive pulmonary TB patients as cases and 35 smear-negative patients as a control). Sampling was done by consecutive sampling. Data were analyzed using the chi-square test and logistic regression test. The analysis can be a significant relationship between residential density, lighting, and humidity with TB incidence. Statistically, indicates that the most related factors are humidity net usage to case TB disease in Tanjungpinang District
\end{abstract}

Keywords - Pulmonary TB, residential density, Lighting, Flooring, Humidity

\section{INTRODUCTION}

Tuberculosis (TB) is a chronic infectious disease caused by the bacterium Mycobacterium tuberculosis. Most of the TB bacteria invade the lungs, there is also attacking other body parts such as bones, glands, and brain commonly called extrapulmonary TB. TB bacteria spread through the air when people who have TB disease are coughing and spreading germs into the air in the form of droplets. When the room was moist and low light, the transmission will be more apt to occur [1].

Tuberculosis is a major health problem world. In 1993, WHO (World Health Organization) has declared TB a global health emergency problems (Global Public Health emergency). At that time estimated to occur 7-8 million cases and 1.3 to 1.6 people estimated to die from TB. In 2010, estimated to have occurred from 8.5 to 9.2 million TB cases and 1.2-1.5 million people died (including TB deaths in people who also suffer from HIV-positive). TB is the second leading cause of death in the world of infectious diseases [2].

In Indonesia, TB is a major public health problem. In 2010, the number of TB cases in Indonesia ranks fourth in the world after India, China, and South Africa, with the number of cases around 0.37 million-0.54 million [2]. Based on the results of Health Research (Riskesdas) in 2010, Period Prevalence of pulmonary TB at the population aged 15 years and over $2009 / 2010$ is based on the diagnosis of health workers through examination of sputum and lung or photos of $725 / 100,000$ population [3].

Figures in Riau Islands province with pulmonary tuberculosis with smear positive improvements, which in 2011 amounted to 1,033 cases and in 2012 the numbers increased to 1,097 cases [4]. In the city of Tanjungpinang incidence of pulmonary TB is still quite high. In 2011 as many as 2,536 suspected pulmonary TB smear positive cases examined and that as many as 216 patients. The year 2012 has been examined as many as 2,065 patients with chronic cough sputum specimens. Total positive for smearpositive bacteria as many as 184 specimens [5].

A high rate of pulmonary tuberculosis patients can be studied from various angles partly because of sanitation and physical environmental conditions of housing that does not meet the health requirements. The risk factors that may affect the residential 
neighborhood incidence of the disease among others ventilation, lighting, cubicle dwelling density, humidity chamber, the room air quality and occupant behavior inside the house [5]. Noting the above problems, researchers are interested in raising the issue in research with the aim to determine the relationship of the physical environment of the home (lighting, floor conditions, humidity and density of occupancy) with pulmonary TB disease events in Tanjungpinang.

\section{RESEARCH METHODOLOGY}

Type of analytical research, observational study with approach Case-control study. The research location in Tanjungpinang, with time for 3 months, to identify subjects who have experienced disease (cases) and does not have the disease (controls). Subject research is all pulmonary TB patients were examined with the results of smear-positive and smear-negative. The research subjects were sampled totaling 70 people, with details of 35 people with smear-positive pulmonary TB as cases and 35 people with smear-negative as a control. Sampling was done by consecutive sampling. Making subject to the control is done by matching or equalization (matching). The mechanism of matching is done by an individual, case-control ratio of 1: 1 .

Analysis using chi-square test with alpha equal to 0.05. Obtained from this test $\mathrm{p}$-value <alpha, then $\mathrm{Ho}$ has rejected it means a significant relationship between variables and when the $\mathrm{p}$ value $>$ alpha, then $\mathrm{Ho}$ is accepted it means there is no significant relationship between the two variables.

\section{RESULT AND DISCUSSION}

TABLE I

ANALYSIS OF RESIDENTIAL DENSITY RELATION WITH THE INCIDENCE OF PULMONARY TB IN TANJUNGPINANG

\begin{tabular}{|c|c|c|c|c|c|c|c|c|}
\hline \multirow{3}{*}{$\begin{array}{l}\text { Residential } \\
\text { Density }\end{array}$} & \multicolumn{4}{|c|}{ Disease incidence of TB } & \multirow{2}{*}{\multicolumn{2}{|c|}{ Total }} & \multirow{3}{*}{$\begin{array}{l}\text { OR } \\
95 \% \mathrm{CI}\end{array}$} & \multirow{3}{*}{$\begin{array}{l}\text { p- } \\
\text { Value }\end{array}$} \\
\hline & \multicolumn{2}{|c|}{ No } & \multicolumn{2}{|c|}{ Yes } & & & & \\
\hline & $\mathrm{n}$ & $\%$ & $\mathrm{~N}$ & $\%$ & $\mathrm{n}$ & $\%$ & & \\
\hline Eligible & 16 & $45,7 \%$ & 8 & $22,9 \%$ & 24 & $34,3 \%$ & 2,842 & 0,044 \\
\hline Ineligible & 19 & $54,3 \%$ & 27 & $77,1 \%$ & 46 & $65,7 \%$ & $\begin{array}{l}1,013- \\
7,976\end{array}$ & \\
\hline & 35 & $100 \%$ & 35 & $100 \%$ & 70 & $100 \%$ & & \\
\hline
\end{tabular}

Based on the statistical test results in Table 1 indicate that the number of eligible residential density with the incidence of TB disease was 27
$(77,1 \%)$ and the number of residential density is not eligible with no incidence of TB disease were 8 $(22,9 \%)$. Results subset of the statistics obtained pvalue $=0.044(p<0,05)$ means that there is a significant relationship between residential density with the incidence of TB. Value OR $=2,842$ means that the house with the ineligible residential density will be at risk of TB incidence 2,842 times than eligible residential density.

In the aspect of the occupant, density showed that most of the research subjects were mainly staying in a bedroom belonging to solid occupants. Each room is inhabited by an average of 4 people (father, mother and two children) with spacious rooms which are mostly not qualified i.e. smaller $8 \mathrm{~m} 2$ or even larger room. It was also observed no actual houses inhabited more than one household, where the children of the household head are married and live at home with his parents.

According to Kepmenkes No.829/Menkes/SK/VII/ 1999, for the measurement of a simple house, spacious bedroom at least $8 \mathrm{~m} 2$ and is not recommended for more than two people. Occupant density is a floor area divided by the number of family members of the occupants. Categorized occupant density to meet the standards $\left(2 / 8 \mathrm{~m}^{2}\right)$ and high density (more than 2 people per $8 \mathrm{~m} 2$ with the provisions of children $<1$ year are not taken into account and the age of 1-10 years is calculated half) [6].

Density dwelling house with the incidence of pulmonary TB in many cases there are on the density of dwelling poor $(63.6 \%)$ whereas in the control condition were the most residential houses on dwelling conditions unfavorable 5 respondents $(22.7$ $\%)$. The results of the bivariate analysis there is a correlation condition residential density with pulmonary TB incidence in Solok with $\mathrm{p}=0.015$, $\mathrm{OR}=5.9595 \% \mathrm{CI}$ (1.586 to 22.328) [7].

Residential density determines the incidence of the disease and death, especially in Indonesia country that still there are so many infectious diseases, such as respiratory disease and all the diseases that spread through the air, for example, tuberculosis is easily transmitted [8]. 
TABLE II

ANALYSIS OF LIGHTING RELATIONSHIP WITH PULMONARY TB INCIDENCE IN TANJUNGPINANG

\begin{tabular}{|c|c|c|c|c|c|c|c|c|}
\hline \multirow{3}{*}{ Lighting } & \multicolumn{4}{|c|}{ Disease incidence of TB } & \multirow{2}{*}{\multicolumn{2}{|c|}{ Total }} & \multirow{3}{*}{$\begin{array}{l}\text { OR } \\
95 \% \mathrm{CI}\end{array}$} & \multirow{3}{*}{$\begin{array}{c}\text { p- } \\
\text { Value }\end{array}$} \\
\hline & \multicolumn{2}{|c|}{ No } & \multicolumn{2}{|c|}{ Yes } & & & & \\
\hline & $\mathrm{n}$ & $\%$ & $\mathrm{n}$ & $\%$ & $\mathrm{n}$ & $\%$ & & \\
\hline Eligible & 14 & $40,0 \%$ & 6 & $17,1 \%$ & 20 & $28,6 \%$ & 3,222 & \\
\hline Ineligible & 21 & $60,0 \%$ & 29 & $82,9 \%$ & 50 & $71,4 \%$ & 9,768 & \\
\hline & 35 & $100 \%$ & 35 & $100 \%$ & 70 & $100 \%$ & & \\
\hline
\end{tabular}

Based on the statistical test results in Table 2 show that the number of qualified lighting with the incidence of TB disease was $29(82,9 \%)$ and the number of lighting ineligible with no incidence of TB disease of $6(17,1 \%)$. Results subset of the statistics obtained $\mathrm{p}$-value $=0,034(\mathrm{p}<0,05)$ means that there is a significant relationship between exposure lighting to the incidence of TB. Value OR $=3,222$ means that the house with ineligible lighting it will be at risk of incidence of TB 3,222 times than house with eligible lighting.

Aspects of lighting is very important because sunlight can kill pathogenic bacteria in the home, such as tuberculosis bacteria. Mycobacterium tuberculosis resistant for 1-2 hours in the air, especially in damp and dark [8]. Kepmenkes RI 829 / Menkes / SK / VII / 1999, the minimum required illumination intensity is 60 lux and no glare.

The reality on the ground a dark room, the sunlight entering less than the maximum and the lights dimmed. That makes it a bigger transmission of TB and TB germs can breed well. Should every home should have a qualified lighting by opening a window every morning, in addition to providing light to kill bacteria also breathes air exchange, so it is good for breathing.

Semarang City Health Center Kedungmundu no relationship lighting with pulmonary TB incidence with $\mathrm{p}=0.023$ and OR 3.889 [10]. Research Wulandari resulted in no lighting relationship with the incidence of TB in Puskesmas Bandarharjo Semarang with $\mathrm{p}=0.001$ and $\mathrm{OR}$ of 11.7. [11]. Research Fatimah lighting a room to sleep an average 41.08 lux. The proportion of the cases that are not eligible and qualified $89.4 \%$ No $10.6 \%$. Lighting control that is $66.7 \%$ are eligible, and there is a relationship between exposure to the TB incidence in Cilacap district in 2008 with a value of $\mathrm{p}=0.003, \mathrm{OR}=4.214 ; 95 \% \mathrm{CI}=1.653$ to 10.74 [12].
Healthy house needs enough light, especially sunlight that contains, among others ultraviolet [13]. The lighting is not sufficient to cause: eye fatigue, accidents, difficult to maintain cleanliness, lowered work productivity. Many types of bacteria can be switched off if the bacteria are getting direct sunlight, as well as tuberculosis bacteria, can die because of light from the ultraviolet rays of sunlight into the room. Preferably morning sun for the morning sunlight contains ultraviolet rays that can kill germs [14].

How to get good lighting inside the house through [14]: First, using sunlight as much as possible for the lighting in the house through a window, the air vents, doors or roofs (skylights). Second, use light colors for floors, walls, and ceiling - sky house. Third, use the light bright enough in accordance with activity at night. Houses with less ventilation effect on the incidence of pulmonary tuberculosis. Home ventilation function to remove contaminated air (bacteria, $\mathrm{CO}_{2}$ ) and replace it with fresh air and clean or for air circulation point of entry of ultraviolet light.

TABLE III

RELATIONSHIP ANALYSIS FLOOR CONDITION WITH THE INCIDENCE OF PULMONARY TB IN TANJUNGPINANG

\begin{tabular}{|c|c|c|c|c|c|c|c|c|}
\hline \multirow{3}{*}{ Flooring } & \multicolumn{4}{|c|}{ Disease incidence of TB } & \multirow{2}{*}{\multicolumn{2}{|c|}{ Total }} & \multirow{3}{*}{ OR $95 \% \mathrm{CI}$} & \multirow{3}{*}{ p-Value } \\
\hline & \multicolumn{2}{|r|}{ Yes } & \multicolumn{2}{|c|}{ No } & & & & \\
\hline & $\mathrm{n}$ & $\%$ & $n$ & $\%$ & $n$ & $\%$ & & \\
\hline Eligible & 13 & $37,1 \%$ & 13 & $37,1 \%$ & 26 & $37,1 \%$ & 1,0 & \\
\hline Ineligible & 22 & $62,9 \%$ & 22 & $62,9 \%$ & 26 & $62,9 \%$ & $0,379-2,637$ & 1,00 \\
\hline & 35 & $100 \%$ & 35 & $100 \%$ & 70 & $100 \%$ & & \\
\hline
\end{tabular}

Based on the statistical test results in Table 3 show that the number of eligible floors condition with the incidence of TB disease was $22(62,9 \%)$ and the number of ineligible floor condition with an incidence of TB disease was $13(37,1 \%)$. Results subset of the statistics obtained p-value $=1,000(\mathrm{p}>$ $0,05)$ means that there is no significant relationship between the floor condition with the incidence of TB.

In the aspect of the condition of the floor shows most of the research subject, both in cases and controls, stay on the floor conditions with relatively similar circumstances. Thus the subject of neither the case nor the comparator has an equal chance to be exposed and suffer from pulmonary tuberculosis. This is due to the similarity in the state of condition 
of the floor between the respondent and the respondent control cases.

The results of a survey showed the majority of respondents have not a permanent home floor, much was made of the land and not in ceramics, with cement floors are cracked or rough cement. Though the ground floor has a role in the occurrence of pulmonary TB. The house with a dirt floor will cause moist and stuffy, which would prolong the survival of the TB germs, it is necessary to be coated with a layer of cement or ceramic watertight.

According to Keputusan Menteri Kesehatan RI No.829/Menkes/SK/VII/1999, the type of flooring that meets the health requirements is watertight and easy to clean. Flooring materials such as plaster, tile, porcelain or ceramic. Water-resistant flooring material can avoid the rising groundwater so as to prevent moisture. Type of floor is made of materials that do not meet health requirements can be a place of growth and development of pathogenic microorganisms one of which is the bacteria that causes lung tuberculosis is Mycobacterium tuberculosis [15].

Research Wulandari in Puskesmas Bandarharjo Semarang that there is no relation floor with TB incidence with $\mathrm{p}=0.370$ [11]. Research Rianda resulted in no relation floor with pulmonary $\mathrm{TB}$ incidence in Solok ( $\mathrm{p}=1.000$, OR $=1$ CI: $95 \%$ (from 0.059 to 17.065$)$ [7].

Type of floor is made from the ground is a good medium for the growth of Mycobacterium tuberculosis, residential density associated with a floor area of houses to be adapted to the number of inhabitants, the denser the number of occupants of the faster transmission occurs

TABLE IV

ANALYSIS OF THE RELATIONSHIP HUMIDITY WITH PULMONARY TB INCIDENCE IN TANJUNGPINANG

\begin{tabular}{|c|c|c|c|c|c|c|c|c|}
\hline \multirow{3}{*}{ Humidity } & \multicolumn{4}{|c|}{ Disease incidence of TB } & \multirow{2}{*}{\multicolumn{2}{|c|}{ Total }} & \multirow{3}{*}{$\begin{array}{c}\text { OR } 95 \% \\
\text { CI }\end{array}$} & \multirow{3}{*}{$\begin{array}{c}\mathrm{p}- \\
\text { Value }\end{array}$} \\
\hline & \multicolumn{2}{|c|}{ Yes } & \multicolumn{2}{|c|}{ Yes } & & & & \\
\hline & $\mathrm{n}$ & $\%$ & $\mathrm{~N}$ & $\%$ & $\mathrm{n}$ & $\%$ & & \\
\hline Eligible & 17 & $48,6 \%$ & 8 & $22,9 \%$ & 25 & $35,7 \%$ & 3,1 & \\
\hline Ineligible & 18 & $51,4 \%$ & 27 & $77,1 \%$ & 45 & $64,3 \%$ & 8,932 & \\
\hline & 35 & $100 \%$ & 35 & $100 \%$ & 70 & $100 \%$ & & \\
\hline
\end{tabular}

Based on the statistical test results in Table 4 show that the number of eligible humidity with the incidence of TB disease was $27(77,1 \%)$ and the number of ineligible humidity with no incidence of TB disease were $8(22,9 \%)$. Results subset of the statistics obtained $p$-value $=0,025(p<0,05)$ means that there is a significant relationship between humidity to the incidence of TB humidity. Value OR $=3,188$ means that the house with ineligible humidity it will be at risk of incidence of TB 3,188 times than house with eligible humidity.

The reality on the ground there is a house that moisture does not qualify. There is a high temperature so the humidity is low or vice versa, so that the mycobacterium tuberculosis bacteria can breed well. Type of floor is a risk factor for pulmonary tuberculosis as well as from the ground floor has a role on the incidence of pulmonary tuberculosis because of the tendency will cause moisture to facilitate the transmission of diseases of pulmonary tuberculosis. Water-resistant flooring material can avoid the rising groundwater so as to prevent moisture.

High humidity can increase the growth of bacteria that cause disease. One of them is Micro bacterium tuberculosis bacteria. Comfortable and good humidity is $40-70 \%$ [16]. Research Fatimah sleeping room humidity average of $72.89 \%$. Humidity in cases that do not qualify for $78.8 \%$, $59.1 \%$ were in control. Bivariate test results there is a relationship of moisture with the incidence of $\mathrm{TB}$ in Cilacap District (the District: Sidareja, Cipari, Kedungreja, Patimuan, Gandrungmangu, Bantarsari) in 2008 with a value of $\mathrm{p}=0.024$ and $\mathrm{OR}=2.571$ [12]. Research Wulandari obtained similar results that there is a relationship between humidity with the incidence of $\mathrm{TB}$ in Puskesmas Bandarharjo Semarang with $\mathrm{p}=0.001$ and $\mathrm{OR}=13.14$ [11]. Research Mereta which conducts research in Puskesmas Kedungmundu Semarang where there is an association between exposure to the incidence of pulmonary $\mathrm{TB}$ with a value of $\mathrm{p}=0.032$ and $\mathrm{OR}=$ $4.033[10]$.

Another study conducted by Sugiarto also showed that states there is a relationship between humidity with pulmonary TB incidence with p-value $=0.001$ and $\mathrm{OR}=4.8$, which means that respondents who live in houses with humidity that are not eligible to have the risk 4.8 times greater risk of pulmonary TB 
compared to respondents with humidity eligible [17].

Humidity has the potential to increase the exposure of persons who are vulnerable to infectious respiratory diseases and may increase the likelihood of transmission. This is because their proximity makes contact with the air contaminated with bacteria that cause infection [18].

Humidity caused by non-qualified ventilation and solid occupants. Ventilation is not qualified to make light of the sun cannot get into the house to increase the humidity in the house. Hence the importance of ventilation researchers hopes in future studies includes variables vents in each room.

Community, Education, Employment, income and lower social classes tend to have a house with a solidstate residents, inadequate ventilation, and the room polluted, these factors will increase the risk of TB [19].

\section{CONCLUSION}

There is no significant relationship between the state store houses with a TB incidence. As for the other variables significant correlation between the density of occupancy, lighting, and humidity with the incidence of TB in the city of Tanjungpinang. Housing conditions have not met the requirements should be programmed to do repairs. The Role of Local Government and the Department of Health in order to control pulmonary $\mathrm{TB}$ for example by increasing promotion and preventive activities in addressing the environmental health community residences. Increase knowledge and awareness of the importance of healthy living, prevention of disease incidence of pulmonary tuberculosis. Prevention is better than treatment. One of the efforts is through counseling by health workers and health volunteers, who all comes down to community empowerment create an independent community.

\section{REFERENCES}

[1] Department of Health RI. (2007) Buku Panduan Pos TB Desa. Direktorat Jenderal Pengendalian Penyakit Dan Penyehatan Lingkungan. Jakarta : Depkes RI.

[2] WHO. (2011) Global Tuberculosis Control; WHO Report 2011. World Health Organization. Jeneva

[3] Kemenkes RI. (2010) Riset Kesehatan Dasar. Badan Penelitian Dan Pengembangan Kesehatan.

[4] Dinas Kesehatan Kota Tanjungpinang. (2012) Profil Dinas Kesehatan Kota. Dinas Kesehatan Kota Tanjungpinang. Provinsi Kepulauan Riau.
[5] Gunawan, K. Mardani, Suhardini, Mahastuti, Priyanto, B., Gunanto, Ismaryani, Gunanto, Maryono A., (2003) Petunjuk Teknis Penilaian Rumah Sehat Propinsi DIY. Yogyakarta: Dinas Kesehatan dan Kesejahteraan Sosial Propinsi DIY.

[6] Mukono, H.J. (1999) Prinsip Dasar Kesehatan Lingkungan. Surabaya: Airlangga University Press. Hal 155-157.

[7] Rianda Putra. (2000) Hubungan Perilaku dan Kondisi Sanitasi Rumah dengan Kejadian Tb Paru di Kota Solok Tahun 2011. Universitas Andalas, Padang, 2011.

[8] Soemirat Juli. (2000) Epidemiologi Lingkungan, Yogyakarta : Gajah Mada University Press

[9] Widoyono, (2008) Penyakit Tropis Epidemiologi, Penularan, Pencegahan, Pemberantasannya, Jakarta: Erlangga.

[10] Mareta Anggie, (2012) Hubungan Antara Kondisi Fisik Rumah Dengan Kejadian Tb Paru Di Wilayah Kerja Puskesmas Kedungmundu Kota Semarang, Jurnal Skripsi, http://journal.unnes.ac.id/sju/index.php/ujph/article/view/9 60 diakses tangal 13 Agustus 2013.

[11] Wulandari, Fitri. (2012). Analisis Spasial Tuberkulosis Paru BTA Positif di Jakarta Selatan Tahun 2006-2010. Universitas Indonesia.

[12] Fatimah, S. (2008) Faktor Kesehatan Lingkungan Rumah yang Berhubungan Dengan Kejadian TB Paru di Kabupaten Cilacap (Kecamatan Sidareja, Cipari, Kedungreja, Patimuan, Gadrungmangu, Bantarsari Tahun 2008. Semarang: Jurnal FKM UNDIP.

[13] Fahmi Umar, (2005). Manajemen Penyakit Berbasis Wilayah; Paradigma Kesehatan Lingkungan, Penerbit Buku Kompas, Jakarta.

[14] Department of Health RI. (2000) Peraturan Menteri Kesehatan RI tentang Rumah Sehat, Jakarta

[15] Departement of Health RI. (2005) Pedoman Nasional Penanggulangan Tuberculosis. Dirjen P2M dan Bidang Penelitian dan Pengembangan Kesehatan. Jakarta : Depkes RI. Hal 1-21 cetakan ke 5.

[16] Department of Health RI. (2004) Kajian Riset Operasional Intensifikasi Pemberantasan Penyakit Menular Tahun 19982003. Dirjen P2M dan Bidang Penelitian dan Pengembangan Kesehatan. Jakarta: Depkes RI.

[17] Sugiarto, Agus. (2004). Faktor-faktor Yang Mempe-ngaruhi Kejadian Tuberkulosis Paru BTA + Pada Penghuni Rumah Kebun Di Bengkulu Utara. Tesis, Fakultas Kesehatan Masyarakat Universitas Indonesia

[18] Gustafson, P., Gomes, V.F., Vieira, C.S., Rabna, P., Seng, R., Johansson, P., Sandström, A., Norberg, R., Lisse, I., Samb, B., Aaby, P., Nauclér, A. (2004). Tuberculosis in Bissau: Incidence and Risk Factors in an Urban Comuunity in Sub-Saharan Africa. International Journal of Epidemiology 2004; 33 (1) : 163-172.

[19] Wardani, D.W.S.R., Lazuardi, L., Mahendradhata, Y., Kusnanto, H. (2014). Structured Equation Model of Tuberculosis Incidence Based on Its Social Determinants and Risk Factors In Bandar Lampung, Indonesia. Open Journal of Epidemiology; 4:76-83. Available from: http://dx.doi.org/10.4236/ojepi.2014.420 